\title{
Managerial Competences, COHERent With THE PROCESS OF ORGANISATIONAL LEARNING IN CONTEMPORARY COMPANIONS
}

\author{
KOMPETENCJE MENEDŻERSKIE SPÓJNE \\ Z PROCESEM ORGANIZACYJNEGO UCZENIA SIĘ \\ WE WSPÓŁCZESNYCH PRZEDSIĘBIORSTWACH
}

\begin{abstract}
Contemporary companies operate in a state of perpetual changes, adopting to them or exceeding them, striving for the ideal state. At the organisational level, they ensure not only survival, but also undisturbed development. The model of functioning that is most closely reflected in such an endeavour is an organisation in which such scientific disciplines as a learning organisation, organisational learning or knowledge management are permeated. At the group level, this pursuit depends largely on managerial competence, which illustrates the effectiveness of team management. This is strongly correlated with the amount of talent, skills and knowledge held by the manager, supported by appropriate personality traits, experience and the developed behaviours. Development at the individual level, on the other hand, as based on openness to experience and self-reflection, is not oriented solely on the results it achieves. The aim of this article is to detail the determinants of the development of an enterprise as a Metanoic Organisation, with a particular emphasis on the managerial competences consistent with the process of organisational learning.
\end{abstract}

\section{STRESZCZENIE}

Współczesne przedsiębiorstwa działają w warunkach nieustającej zmiany, adaptując się lub wyprzedzając zmiany, dążą do stanu idealnego. Na poziomie organizacyjnym zapewniając nie tylko przetrwanie, ale także niezakłócony rozwój. Modelem 
funkcjonowania, który w największym stopniu odzwierciedla takie dążenie, jest organizacja, w której przenikają się takie koncepcje jak: organizacja ucząca się, organizacyjne uczenie się czy zarządzanie wiedzą. Na poziomie grupy dążenie to zależne jest w dużej mierze od kompetencji menedżerskich, które obrazują skuteczność w zarządzaniu zespołem. Jest to silnie powiązane z sumą posiadanych przez menedżera zdolności, umiejętności i wiedzy, wspartej na odpowiednich cechach osobowości, jak również z doświadczeniem i wypracowanymi sposobami zachowania. Natomiast rozwój na poziomie jednostki, dla której podstawą jest otwartość na doświadczenie i autorefleksja, nie jest zorientowany wyłącznie na osiągane przez nią rezultaty. Celem artykułu jest określenie uwarunkowań rozwoju przedsiębiorstwa jako organizacji żywej, przekształcającej się, ze szczególnym uwzględnieniem kompetencji menedżerskich spójnych z procesem organizacyjnego uczenia się.

KeYwords: Learning Organizations, Metanoic Organization, Intelligent organization, Organizational Learning, Knowledge Management, Managerial Competencies, Leader

SŁOWA KLUCzOWE: organizacja uczaca się, organizacja inteligentna, organizacyjne uczenie się, zarządzanie wiedza, kompetencje menedżerskie, lider

\section{WPROWADZENIE}

Współczesne przedsiębiorstwa działają w warunkach, w których jedynym pewnym zjawiskiem są zmiany. Widoczne są przyspieszanie rozwoju technologii, rosnące wymagania co do jakości, ciągła konieczność walki z konkurencją, dla której przestają istnieć wszelkie granice. Szybkość i intensywność tych zmian w otoczeniu organizacji stale wzrasta, stawiając przed przedsiębiorstwami coraz to nowe wyzwania i wymagania jednocześnie. Organizacje odnoszą się do procesu ciągłych przemian, ich liczby i skutków w różny sposób. Traktując je i myśląc o nich jak o zagrożeniach, możliwościach lub też jak o czymś, co jest wsobnym elementem kreacji rzeczywistości. Na przykład reakcją na zmiany w latach 70. XX w. było stawianie pytania: „co?”. W latach 90. już „jak?”, a aktualnie: „dlaczego?” i „kto?”.

Chociaż za każdym razem rozpatrywane są nieco zbliżone do siebie zjawiska, to kwestia tworzenia przedsiębiorstwa we współczesnych czasach roznieca coraz większą ciekawość i fascynację zgłębiania tematu. Można by powiedzieć, że jest to strategia kreatywna, której głównym celem jest 
kreowanie i zaspakajanie potrzeb oraz jednoczesne projektowanie innowacyjnych metod, które cechuje szybkie rozeznanie i właściwa reakcja na otoczenie (Czerska, Nogalski, 2001, s. 544-545). Ostatecznie, istota tego może wybiegać dalej, jest to bardziej zdolność organizacyjnego uczenia się i powstająca w wyniku tego wiedza. Zatem przyszłość należy (Czubasiewicz, 2001 s. 107) do takich przedsiębiorstw, których zasób strategiczny odpowiada formule: „informacja + wiedza + kreatywność”, które produkują/kupują wiedzę, wykorzystując i sprzedając, realizują „wartość dodaną”. Aby działo się to już teraz, warunkiem zajścia tych procesów jest ponowne zdefiniowanie podstawowych organizacyjnych funkcji zarządzania oraz dostosowanie ich nie do kontroli korzystania $z$ materialnych zasobów, ale do zarządzania wiedzą i jej wykorzystania (Śliwa, 2001, s. 95). W ten sposób wiedza staje się kluczowym zasobem dla organizacji, spychając wszystkie pozostałe do roli uzupełniających ją czynników wytwórczych. Jednak, aby była to ewolucja, a nie rewolucja, należy szukać opcji dla współistnienia dwóch modeli zarządzania jednocześnie. Odpowiedzią na to było powołanie do życia koncepcji organizacji uczącej się.

\section{EWOLUCJA POJĘCIA ORGANIZACJI - ORIENTACJA ŻYWA (METANOIC ORgANizATION)}

Jednym z celów cząstkowych tego artykułu jest określenie uwarunkowań rozwoju przedsiębiorstwa jako organizacji żywej, przekształcającej się. Aby to uczynić, we wstępie zostały nakreślone zręby tzw. nowej nauki, w której dochodzi do przedefiniowania koncepcji zasobów ekonomicznych, i w konsekwencji - do zmiany pojmowania samego zjawiska organizacji. Należy tu wspomnieć, że zamiana ta nie jest jedyną w historii myśli organizacyjnej. Podobnych zmian było wiele, tak jak wiele było opisujących organizacje kodów i schematów poznawczych. W tym paragrafie zostaną one przedstawione przy wykorzystaniu metafor (Sułkowski, 2011, s. 55-58). Otóż na pewnym etapie poznawania organizacji odpowiadającej określonym warunkom gospodarowania istniała dominująca koncepcja organizacji, uwzględniająca właśnie te konkretne warunki i odpowiadające im konkretne kody (Morgan, 1998). Zwerbalizowane w ten sposób ujęcie opatrujemy nazwą archetypu organizacji i możemy mówić o dwóch jego poziomach: teoretycznym i pragmatycznym. 
Poziom teoretyczny znacząco wykracza poza ramy tematyczne artykułu i zostaje celowo, mimo swojej rangi, pominięty. Natomiast poziom pragmatyczny wyróżnia cztery podstawowe archetypy, z których każdy przedstawia odmienną perspektywę. Są nimi: organizacja jako maszyna, organizacja ekologiczna żywa, organizacja neuronowa i społeczny archetyp organizacji. Chcąc uzyskać pełen wgląd w to, jakie uwarunkowania muszą zaistnieć dla organizacji żywej, należy przedstawić w choćby minimalistyczny sposób inne archetypy, lecz na tyle zwięzły, aby uzyskany ogląd dawał całkowite spektrum zagadnienia. Historycznie pierwszym i bezwzględnie dominującym w świadomości kadry kierowniczej konceptem jest postrzeganie organizacji jako maszyny, racjonalnego tworu, zaprojektowanego i wykonanego w sposób alienacyjny przez zewnętrznego organizatora. To przywódcy i konsultanci projektują organizacje, ludzie w nich są zasobami, które należy starannie uszeregować w schemacie organizacyjnym, niczym trybiki w maszynie. Natomiast zmiany muszą być planowane i mapowane w strategiach, a potem starannie implementowane zgodnie z planem (Laloux, 2015, s. 40). Archetyp ten był nie tylko pierwszym świadomie użytym przez człowieka, ale należy również zauważyć, że był on też dostosowany, w sposób perfekcyjny, do pewnego wzorca kulturowego i religijnego. W swojej czystej postaci, co już zostało powyżej zasygnalizowane, nawiązuje on do procesu poznawania opartego na metodologii redukcjonistycznej, co umożliwiło mu odegranie ważnej roli w dziedzinie zarządzania, a przez to ukształtowało tę wizję na pokolenia. Kolejna interpretacja narodziła się wskutek zainteresowania się problemem wewnętrznych i zewnętrznych zmian organizacyjnych, jak również dzięki faktowi powstawania i zanikania całych generacji przedsiębiorstw. Było to również inklinacją dla zaistnienia zarządzania strategicznego, ujmowania organizacji jako bytu organizacyjnego w analizach otoczenia. Takie odniesienie do biologii w myśleniu o podmiocie znalazło również odbicie w używanej terminologii. Takie stwierdzenia jak cykl życia organizacji, homeostaza, entropia itd. dały początek zaistnieniu w nauce o zarządzaniu novum, jakim była ogólna teoria systemów, która pierwotnie rozwinęła się przy antropomorficznej analizie organizmów żywych. Niemniej jednak ekologiczny archetyp nie poprzestaje tylko na odniesieniu się do żyjących systemów. Oprócz wyróżnionego, wpisują się tu jeszcze m.in. teoria sytuacyjna organizacji i zarządzania czy choćby teorie systemów 
socjotechnicznych. Jednak główną pobudką ku temu było przekierowanie uwagi na budowanie organizacji otwartych na otoczenie oraz uwzględniających naturalny charakter zachowań człowieka. Podstawowe zasady, wokół których skonstruowany został ekologiczny archetyp organizacji żywej, to:

- organizacja jest otwarta na wpływy otoczenia,

- jest ona układem wzajemnie uzależnionych systemów,

- zarządzanie polega na zapewnianiu współpracy między poszczególnymi częściami organizacji,

- nie istnieją idealne zasady podziału i organizacji pracy, więc potrzebne są różne podejścia w zarządzaniu organizacją,

- warunki otoczenia będą dyktowały typ istniejącej organizacji,

- dostosowanie organizacji do otoczenia wyraża się różnorodnością strukturalnej formy,

- strukturalne dostosowanie organizacji do otoczenia jest decydujące dla jej przetrwania,

- ekologia organizacyjna jest ważnym atrybutem dowolnej populacji organizacyjnej,

- organizacje mają określony cykl życia: powstają, dojrzewają i znikają (Śliwa, s. 112).

Ekologiczna wizja organizacji, będąc metaforycznym obrazem, korzysta jedynie z analogii; pozostaje bardzo racjonalna, choć zakłada, że wiele rozwiązań stosowanych przez ożywioną przyrodę może być wzorem do naśladowania.

\section{UWARUNKOWANIA ORGANIZACJI UCZĄCEJ SIĘ}

Koncepcja organizacji uczącej się, żywej wywodzi się z ciągłej potrzeby dostosowywania sposobów zarządzania organizacją do zmian zachodzących w jej rynkowym otoczeniu, ale nie tylko. Jest również następstwem zaspokojenia potrzeby osiągania przewagi konkurencyjnej, o czym nie należy zapominać. Dynamika ewolucji podyktowana jest poszukiwaniem coraz to efektywniejszych metod, dlatego u podstaw koncepcji organizacji uczącej są takie założenia jak:

- po pierwsze, organizacje, podobnie jak organizmy żywe, mogą się uczyć, a uczenie się jest przyjęte jako strategiczna wartość, 
- po drugie, przyszłość organizacji zależy od wszystkich jej członków, a oni są tego świadomi, dlatego w procesie uczenia się uczestniczą wszyscy; organizacja tworzy warunki dla rozwoju na poziomie jednostki, przy czym newralgiczne jest uruchomienie tego na poziomie zespołu,

- po trzecie, organizacja musi odpowiednio motywować do szeroko rozumianej innowacji, podejmując to poprzez aktywizowanie sfery umysłowej i emocjonalnej, utrzymując je w zgodności z działaniem, czego efektem jest głęboko osobiste zaangażowanie jej członków, jednak z uwzględnieniem faktu uczenia się przez każdego w różny sposób,

- po czwarte, proces uczenia się winien być ciągły i świadomy, a nie pozostawiony losowi (Senge, 2011, s. 21).

Świadomość realizacji procesów organizacyjnego uczenia się na trzech poziomach: indywidualnym, grupowym i całej organizacji oraz zarządzanie tymi procesami odróżnia współczesne organizacje od form je poprzedzających (Mikuła, 2001, s. 25).

Zapraszani do kreacji wspólnej wizji ludzie uczą się ożywiać poczucie zaangażowania w grupie, tworząc wspólną przyszłość, będąc aktywni „tu i teraz", mogą się do jej realizacji przybliżać. Opanowanie tych dwóch dyscyplin pozwala grupom i osobom przechodzić od myślenia reaktywnego do twórczego, czyli proaktywnego, przyjmując jednocześnie odpowiedzialność za wyniki.

Koncepcja, jaką jest organizacyjne uczenie się, jest kluczem do wykrywania i korygowania błędów na poziomie jednostki, grupy i całej organizacji. Cechuje ją kognitywne podejście, koncentrujące się na badaniu procesów myślowych - tego, jak tworzą się i zmieniają indywidualne modele mentalne i struktury poznawcze (preferencje, założenia, oceny czy wartości).

Kolejną cechą organizacyjnego uczenia się jest konstruktywizm, który przesuwa akcent na mechanizmy poznawczo-rozwojowe w relacji między aktywnym podmiotem a jego otoczeniem. Według niego uczenie się jest procesem społecznym. Budującym wspólne rozumienie rzeczywistości poprzez dyskusje, dialog, zbieżne wartości, tradycje myślenia i interpretowania danych, praktyk i zachowań. 


\section{KOMPETENCJE MENEDŻERSKIE SPÓJNE Z PROCESEM ORGANIZACYJNEGO UCZENIA SIĘ}

Dzięki upowszechnianiu omawianych koncepcji - organizacyjnego uczenia się, organizacji uczących się i zarządzania wiedzą - uzyskujemy odpowiedź na pytanie: „jak skutecznie budować przewagę konkurencyjną?”. Naturalnym następstwem jest pojawienie się kolejnego: „jak ten stan osiągnąć?”, a precyzyjniej: „dzięki komu” lub „jakiemu konceptowi jaźni jest to możliwe?”.

Aby menedżer był skuteczny, zgodnie z tezą Petera Druckera, musi zadawać sobie pytanie „czego się ode mnie oczekuje?”. Dzięki temu zorientowany jest na zewnątrz, na rezultaty, jakie ma osiągnąć (Drucker, 2004, s. 63-80). W organizacji uczącej się dochodzi zorientowanie do wewnątrz: „jak mam umożliwić to zespołowi, aktywnie pracując na rzecz innych, współdziałając?”. Do tego potrzebna jest wiedza jawna o faktach, koncepcjach i teoriach, a konkretnie o organizacji uczącej się, organizacyjnym uczeniu się, zarządzaniu wiedzą czy choćby zarządzaniu zasobami ludzkimi itd. I niejawna, przyjmująca postać ogółu treści utrwalonych w ludzkim umyśle w wyniku zdobytych doświadczeń oraz uczenia się. W węższym znaczeniu mowa tu o tym, co stanowi osobisty stan poznania człowieka wskutek oddziaływania na niego rzeczywistości organizacji uczącej się (Szczepańska-Woszczyna, 2016, s. 72-83). Zatem wskazane by było, aby menedżer miał doświadczenie, a dzięki niemu wyobrażenie, jak powinien proces organizacyjnego uczenia tworzyć i nim sterować, przede wszystkim poprzez jego zwalnianie lub katalizowanie. Jednak zanim to będzie możliwe, należy podkreślić, że to, co o tym wie, musi mieć zinternalizowane. Musi przez cały czas swoją postawą i tym, kim jest, prezentować innym pożądane zachowania.

Doświadczenie menedżera może być rozwijane przez praktykę, obserwację, trening kierowniczy, coaching lub mentoring. Coraz częściej też same umiejętności coachingowe pojawiają się jako filozofia zarządzania oraz jako metodyka ułatwiająca zmianę, poprzez wspieranie samoukierunkowanego uczenia się i osobistego rozwoju (Szejniuk, 2015).

\section{Podsumowanie}

Organizacja ucząca się to wspólnota pracowników i kierownictwa, oparta na jawności i odmienności opinii oraz poglądów. Jest miejscem, gdzie zachodzi integracja ambicji i aspiracji jej członków, czego następstwem jest wspólnie 
stawiane pytanie: „Jak możemy być lepsi jako firma?”. Dążenie to, będące procesem ciągłego stawania się, potwierdza nieustanną aktualność omawianych koncepcji. W związku z tym współczesne przedsiębiorstwa starają się pozyskiwać niezbędną wiedzę, aby lepiej rozumieć swoje otoczenie i nie tylko się do niego dostosować na zasadzie sprzężenia zwrotnego, ale też wywierać na nie proaktywnie określony wpływ, stając się współautorem rzeczywistości. Dlatego też konkluzja: „przedsiębiorstwo jest tak dobre jak jego ludzie” Erharda Schachela jest w pełni uzasadniona, aczkolwiek bardziej precyzyjne wydaje się stwierdzenie: „przedsiębiorstwo jest tak inteligentne jak jej członkowie, liderzy i decydenci”.

\section{Literatura}

Czerska, M., Nogalski, B. (2001). Kierowanie zmiana w organizacji. W: A. Czermiński $\mathrm{i}$ in. (red.), Zarzadzanie organizacjami, Toruń: Wydawnictwo Dom Organizatora. ISBN 8372850526.

Czubasiewicz, H. (2001). Zarządzanie zasobami ludzkimi, Warszawa: Wydawnictwo Akademickie. ISBN 8391617319.

Drucker, P.F. (2004). Menedżer skuteczny, Warszawa: MT Biznes Ltd. ISBN 8388970062.

Laloux, F. (2015). Pracować inaczej, Warszawa: Wydawnictwo Studio EMKA. ISBN 9788364437939.

Mikuła, B. (2001). Elementy nowoczesnego zarzadzania - $w$ kierunku organizacji inteligentnych, Kluczbork-Kraków: Oficyna Wydawnicza Drukarnia Antykwa s.c. ISBN 838749366X.

Morgan, G. (1998). Images of Organization, San Francisco: Sage Publications. ISBN 1412939798.

Senge, P.M. (2011). Piąta dyscyplina. Teoria i praktyka organizacji uczących się, Kraków: Wolters Kluwer Polska. ISBN 9788326416514.

Śliwa, K.R. (2001). O organizacjach inteligentnych i rozwiazywaniu złożonych problemów zarządzania nim, Warszawa: Oficyna Wydawnicza WSM SIG.

Sułkowski, Ł. (2011). Metafory, archetypy i paradoksy organizacji, „Organizacja i Kierowanie" nr 2(145). ISSN 0137-5466.

Szczepańska-Woszczyna, K. (2016). Kompetencje menedżerskie w kontekście innowacyjności przedsiębiorstwa, Warszawa: Wydawnictwo naukowe PWN. ISBN 9788301188382.

Szejniuk, A. (2015). Coaching - narzędzie rozwoju kompetencji zawodowych, „Journal of Modern Science" 3/26. ISSN 1734-2031. 